\title{
First records of two Amazonian species of Zethus (Zethoides) Fox, 1899 (Hymenoptera, Vespidae, Eumeninae) in Atlantic Forest fragments in São Paulo state, Brazil
}

\author{
Rogério Botion Lopes ${ }^{1 *}$ and Fernando Barbosa Noll ${ }^{2}$ \\ 1 Universidade de São Paulo, Faculdade de Filosofia, Ciências e Letras de Ribeirão Preto, Departamento de Biologia. Av. Bandeirantes, \\ 3900. CEP 14040-901. Ribeirão Preto, São Paulo, Brazil \\ 2 Universidade Paulista "Júlio de Mesquita Filho", Instituto de Biociências, Letras e Ciências Exatas, Departamento de Zoologia e \\ Botânica, Laboratório de Aculeata. Rua Cristóvão Colombo, 2265. CEP 15054-000. São José do Rio Preto, São Paulo, Brazil \\ * Corresponding author. E-mail: rbotlopes@gmail.com
}

\begin{abstract}
Zethus Fabricius, 1804 is the largest genus in the subfamily Eumeninae with over 250 species. Its Neotropical representatives are divided into three subgenera: Z. (Zethus) Fabricius, 1804; Z. (Zethusculus) de Saussure, 1855; and Z. (Zethoides) Fox, 1899. Two specimens were collected in the northeastern region of São Paulo state, Brazil belonging to two species of the latter subgenus: $Z$. (Zethoides) lobulatus de Saussure, 1855 and $Z$. (Zethoides) rugosiceps Fox, 1899. These species have so far only been collected in the Amazon Forest and these findings not only expand the latitude of the species' distribution but also their occurrence to the Atlantic Forest as well.
\end{abstract}

Key words: Neotropical mason wasps; potter wasps; distribution

\section{INTRODUCTION}

Zethus Fabricius, 1804 is the most speciose genus of the Eumeninae with 258 valid species (Lopes and Noll 2014; Cooper 2014; Lopes and Hermes 2015). Its 223 New World species are, so far, divided into three subgenera: Z. (Zethus) Fabricius, 1804, Z. (Zethusculus) de Saussure, 1855 and $Z$. (Zethoides) Fox, 1899, which are further divided in species groups. The latter subgenus can be identified mainly by the three-lobate apical lamella of the third tergum and the laterally tapered apical lamella of the third sternum (Bohart and Stange 1965). The subgenus Zethoides is composed of 42 species distributed in eight groups, whose diversities and ranges vary greatly, from monotypic assemblies that are each restricted to a limited area (e.g., Z. aztecus group to Mexico and $Z$. minimus group to Argentina) to groups occurring from North to South America with over 10 species each (e.g., Z. olmecus and Z. bilglumis groups) (Bohart and Stange 1965).

Here we report range extensions for $Z$. lobulatus from the $Z$. clypearis group and Z.rugosiceps, from the Z. biglumis group, two species known to occur in the Amazon Forest (Bohart and Stange 1965).

\section{MATERIALS AND METHODS}

Two specimens deposited in the entomology collection of the Instituto de Biociências, Letras e Ciências Exatas (IBILCE) of the Universidade Estadual Paulista "Júlio de Mesquita Filho" were identified by Bolívar Rafael Garcete-Barrett as Zethus lobulatus and Z. rugosiceps, and their identifications were later confirmed using keys from Bohart and Stange (1965).

The specimens were examined and photographed under a Leica MZ16 stereoscope and the images were obtained with a Leica DFC295 camera, using Leica Application Suite and followed by image-stacking in CombineZP.

The specimen of $Z$. lobulatus is a female collected in Barretos, São Paulo state, Brazil (Figures 1-5) and the female specimen of $Z$. rugosiceps was collected in Sales, also in São Paulo state (Figures 6-9).

Maps were plotted using DIVA-GIS 7.5.0 (Hijmans et al. 2012) with shape files obtained from the MMA (2015) and TNC (2013) web sites.

\section{IDENTIFICATION}

Zethus lobulatus and $Z$. rugosiceps belong to $Z$. clypearis and $Z$. biglumis groups respectively, which are presumably closely related to each other (Bohart and Stange 1965). These groups have remarkable morphological resemblance, both presenting a very narrow sub-humeral area of the pronotum (Figure 10) 
- except for (Z. rugosiceps Figure 11) - when compared to specimens from other species groups (Figure 12) and a broad tegula with outer margin posteriorly bowed (Figure 13-14) rather than evenly convex (Figure 15). This leaves only the punctuation in the dorsal face of pronotum as a differential feature for each group, being striate in the specimens of the $Z$. clypearis group (Figure 16) and punctate in the $Z$. biglumis group (Figure 17).

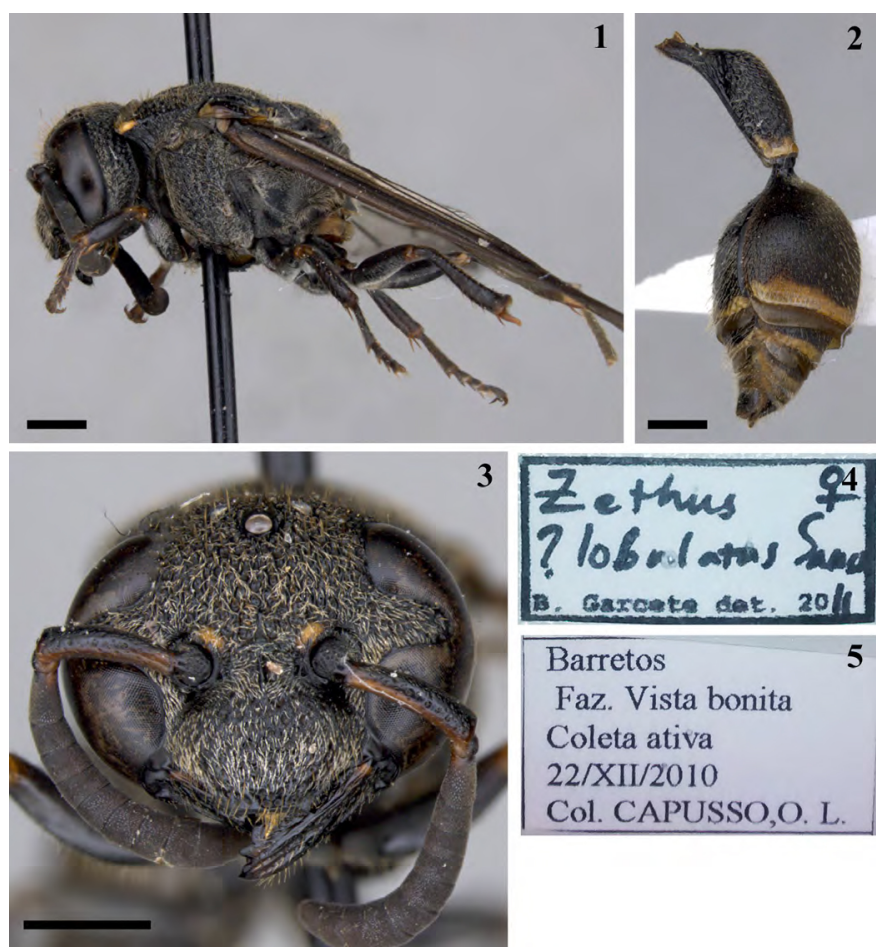

Figures 1-5. Female specimen of Zethus lobulatus collected in São Paulo. 1. Habitus. 2. Metasoma, lateral view. 3. Head, frontal view. 4. Identification label. 5. Collection label. Scale: $1.0 \mathrm{~mm}$.
Zethus (Zethoides) lobulatus de Saussure, 1855

Diagnosis (female): Black with yellow markings on top of the antennal sockets, angles of humeri, spots on metanotum and bands from metasomal segments 1-5. Body covered by dense golden pilosity with thick and erect setae. Mandible with subapical reflexed tooth. Apical margin of clypeus straight with subapical edge (Figure 3). Pronotal dorsal surface with oblique striae

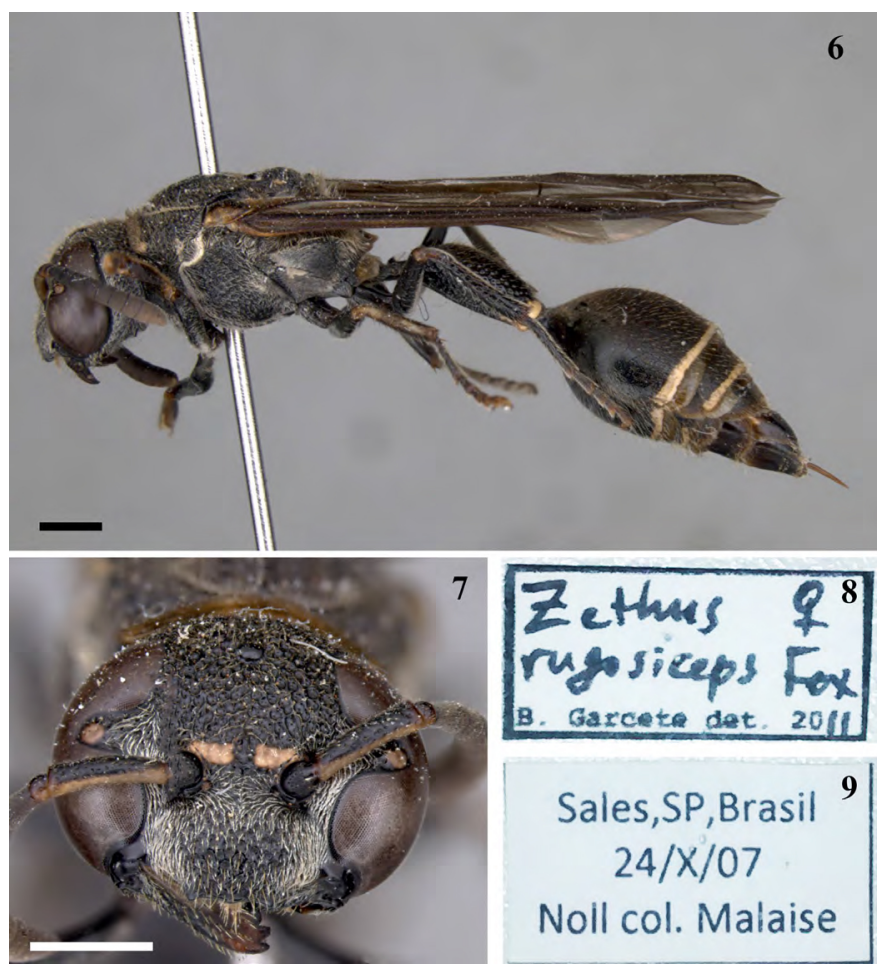

Figures 6-9. Female specimen of Zethus rugosiceps collected in São Paulo. 6. Habitus. 7. Head, frontal view. 8. Identification label. 9. Collection label. Scale: $1.0 \mathrm{~mm}$.
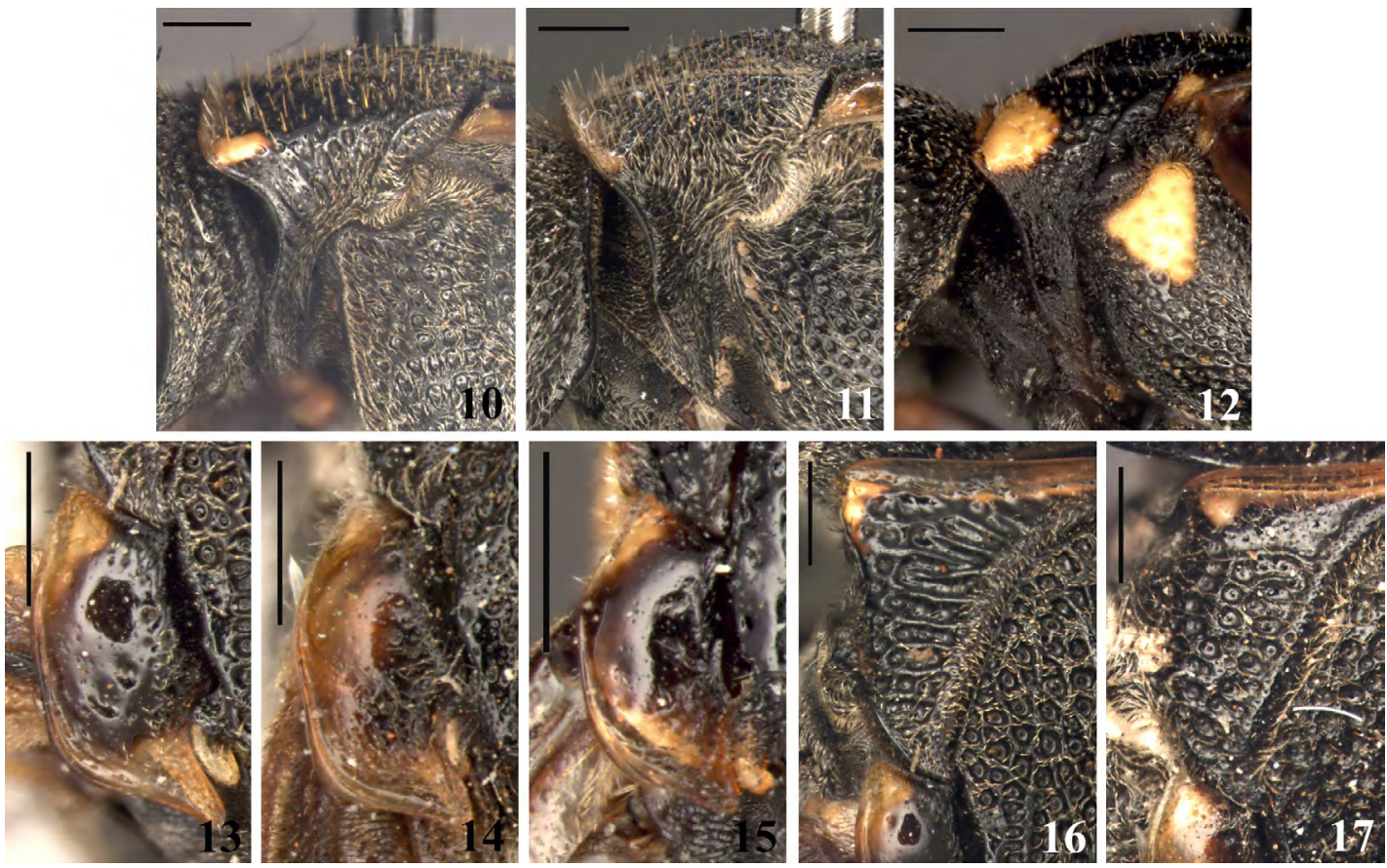

Figures 10-17. Diagnostic features for the Z. biglumis and Z. clypearis groups. 10-12. Pronotum, lateral view. 13-15. Tegula, dorsal view. 16-17. Pronotum, oblique dorsal view. 10, 13, 16. Zethus lobulatus. 11, 14, 17. Zethus rugosiceps. 12, 15. Zethus (Zethoides) guerreroi Zavattari, 1913. Scale: 0,5 mm. 


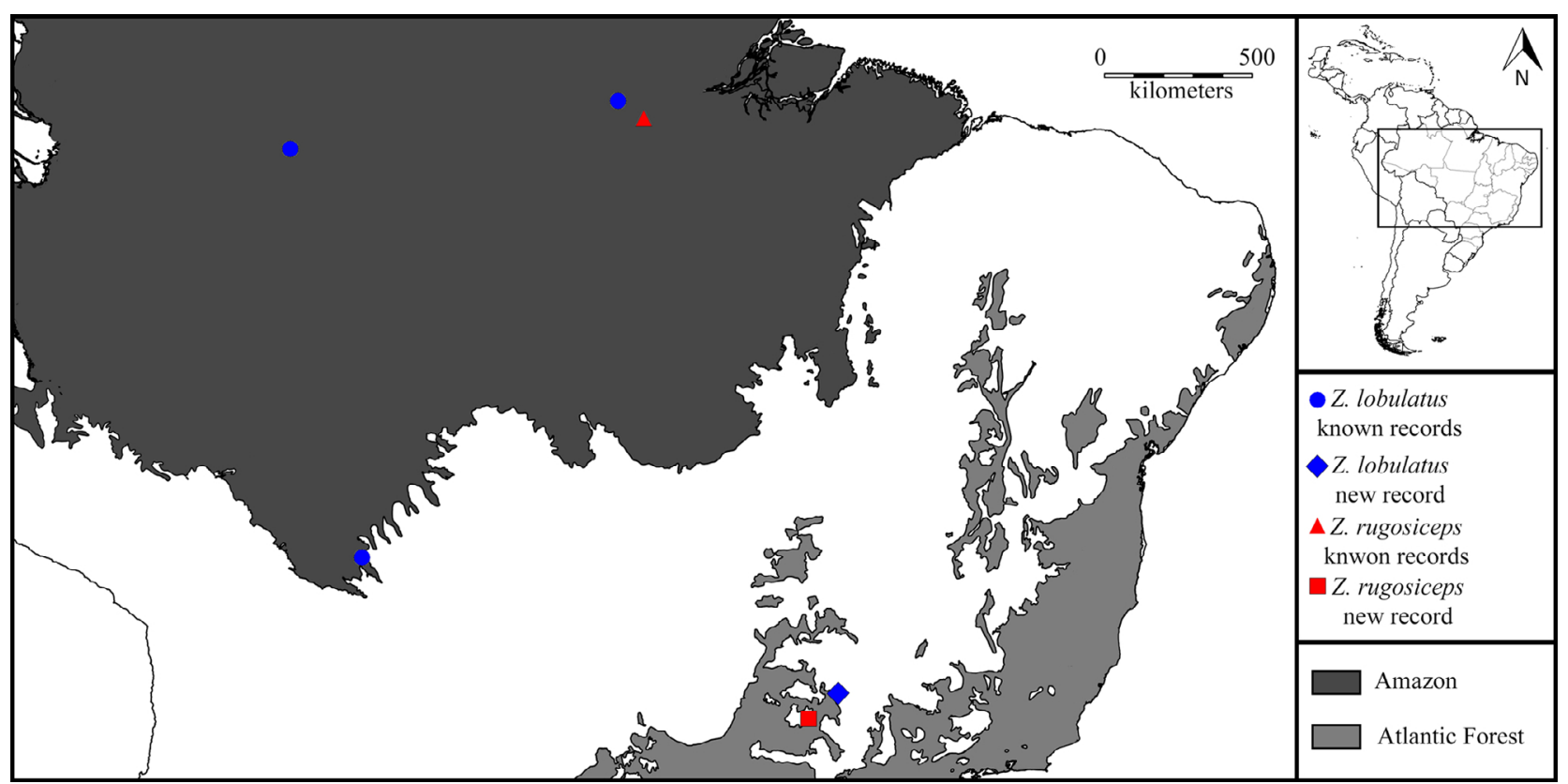

Figure 18. Records of Zethus lobulatus and Z. rugosiceps according to the biome where collected.

(Figure 16). Humeri forming an edge between dorsal and lateral surfaces. First metasomal tergum, on profile, expands more abruptly, becoming angulate and bent before expansion (Figure 2), which is unique in the group. Fore wing length: $9.3 \mathrm{~mm}$.

Distribution: Brazil (Amazonas, Pará, São Paulo); Bolivia.

Observation: The specimen collected in São Paulo is darker and many of the light markings are found wanting. Still, all the other morphological traits are similar, leading to believe it is just a color variation.

Material examined: BRAZIL: 19, Pará, Óbidos (o1 $54^{\prime} 21^{\prime \prime}$ S, $055^{\circ} 30^{\prime} 44^{\prime \prime} \mathrm{W}$ ), no date, no collector (University of California, Davis); 19, São Paulo, Barretos $\left(20^{\circ} 33^{\prime} 13^{\prime \prime} \mathrm{S}, 048^{\circ} 34^{\prime} 11^{\prime \prime} \mathrm{W}\right)$, Faz. Vista Bonita, 22.xii.2010, leg. O.L. Capusso (IBILCE).

\section{Zethus (Zethoides) rugosiceps Fox, 1899}

Diagnosis (female): Black with yellow markings on top of the antennal sockets, base of pronotal carina, spots on scutellum and bands from metasomal segments 1-3. Body covered by dense golden pilosity with thin and erect setae. Mandible with subapical reflexed tooth, which is unique in the group. Apical margin of clypeus biconcave with subapical edge (Figure 7). Pronotal dorsal surface with wide shallow punctures, some coalescent. Humeri rounded (Figure 17). Subhumeral area very broad, when compared to other species in the group. First metasomal tergum, on profile, expands gradually, evenly convex through expansion (Figure 6). Fore wing length: $9.1 \mathrm{~mm}$.

Distribution: Brazil (Pará, São Paulo)

Material examined: BRAZIL: 19, São Paulo, Sales ( $\left.21^{\circ} 20^{\prime} 39^{\prime \prime} \mathrm{S}, 049^{\circ} 30^{\prime} \mathrm{O}^{\prime \prime} \mathrm{W}\right)$, Malaise trap, 24.x.2007, leg. F.B. Noll (IBILCE).

\section{DISCUSSION}

Zethus lobulatus and $Z$. rugosiceps are species that previously have only been recorded in the Amazon Rainforest (Bohart and Stange 1965). Our findings not only greatly expand the distribution of these species, but reveal their occurrence in a new biome, the Atlantic Rainforest (semi-deciduous rainforest) (Figure 18). It is still not rare to report new distributions in Eumeninae (e.g., Garcete-Barrett 2002; Stange 2003; Hermes and Köhler 2004; Grandinete and Noll 2013; Hermes and Garcete-Barrett 2013; Lopes and Noll 2014; Cooper 2014), showing that the group is poorly recorded.

Excluding $Z$. diminutus, the South American species belonging to the $Z$. clypearis and $Z$. biglumis groups have a small latitudinal range and some with very few distribution records (see examined material of the species included in these groups in Bohart and Stange 1965). However, these new findings reveal that we must be cautious before assuming that the known distribution area of a species in these groups is also the true limit of its range. In a similar case, Lopes and Noll (2014) recently documented Z. (Zethoides) biglumis Spinola, 1841 in an Atlantic Forest fragment in São Paulo state; until then was also believed to live only in the Amazon. Thus, our records are the second and third cases of latitudinal, as well as ecosystem/ biome expansions within these species groups in a time span of just two years.

\section{ACKNOWLEDGEMENTS}

We acknowledge CAPES and FAPESP for financial support and to Dr. Lynn Kimsey for the loan of the of the $Z$. lobulatus specimen. 


\section{LITERATURE CITED}

Bohart, R.M. and L.A. Stange. 1965. A revision of the genus Zethus Fabricius in the Western Hemisphere (Hymenoptera: Eumenidae). University of California Publications in Entomology 40: $208 \mathrm{pp}$.

Cooper, M. 2014. Two new species of Zethus Fabricius in the coeruleopennis group (Hymenoptera, Vespidae, Eumeninae). Entomologist's Monthly Magazine 150: 39-42.

de Saussure, H. 1855. Études sur la famille des vespides 3. La Monographie des Masariens et un supplément à la Monographie des Euméniens. Paris/Geneva: V. Masson / J. Cherbuliez. 352 pp. doi: 10.5962/bhl.title.39973

Fabricius, J.C. 1804. Systema piezatorum: secundum: ordines, genera, species, adiectis synonymis, locis, observationibus, descriptionibus. Brunsvigar: Carolus Reichard. 439 pp. doi: 10.5962/bhl.title.10490

Fox, W.J. 1899. Contributions to a knowledge of the Hymenoptera of Brazil. No. 7 - Eumenidae (Genera Zethus, Labus, Zethoides, Eumenes, Montezumia and Nortonia). Proceedings of the Academy of Natural Sciences of Philadelphia 51: 407-464. http:// biodiversitylibrary.org/page/6389592

Garcete-Barrett, B.R. 2002. Notas sobre Eumeninae neotropicales III (Hymenoptera: Vespidae). Boletín del Museo Nacional de Historia Natural del Paraguay 14(1-2): 36-42.

Grandinete Y.C. and F.B. Noll. 2013. Checklist of social (Polistinae) and solitary (Eumeninae) wasps from a fragment of cerrado "Campo Sujo" in the state of Mato Grosso do Sul. Sociobiology 6o(1): 101-106. doi: 10.13102/sociobiology.v6oi1.101-106

Hermes, M. G. and A. Köhler. 2004. Chave ilustrada para as espécies de Vespidae (Insecta, Hymenoptera) ocorrentes no Cinturão Verde de Santa Cruz do Sul, RS, Brasil. Caderno de Pesquisa Série Biologia 16(2): 65-115.

Hermes, M.G. and B.R. Garcete-Barrett. 2013. Notes on Neotropical
Eumeninae, with the description of a new species of Pachodynerus de Saussure (Hymenoptera, Vespidae). Revista Brasileira de Entomologia 57(2): 169-172. doi: 10.1590/Soo8556262013005000010 .

Hijmans, R.J., L. Guarino, C. Bussink, P. Mathur, M. Cruz, I. Barrentes and E. Rojas. 2012. DIVA-GIS. Version 7.5. Accessed at http://www.diva-gis.org, 8 April 2015.

Lopes, R.B. and F B. Noll. 2014. Notes on the Neotropical Zethus Fabricius, 1804 (Hymenoptera, Vespidae, Eumeninae) with the description of two new species from Brazil. Zootaxa 3784(2): 179-186. doi: 10.11646/zootaxa.3784.2.7

Lopes, R. B., and M. G Hermes. 2015. A new species of Zethus (Zethusculus) de Saussure (Hymenoptera, Vespidae, Eumeninae) from Southern Brazil. Revista Brasileira de Entomologia 59(2): 138-140. doi: 10.1016/j.rbe.2015.03.010

MMA. [2015]. Geoprocessamento - Download de dados geográficos. Ministério do Meio Ambiente. Accessed at http://www.mma. gov.be, 20 April 2015.

Spinola, M. 1841. Hyménoptères recueillis a Cayenne en 1839 par M. Leprieur, pharmacien de la Marine Royale. Seconde Partie. Porte-Aiguillons. Annales de la Société Entomologique de France 10: $85-149$.

Stange, L. A. 2003. Review of Zethus Fabricius from the West Indies (Hymenoptera: Vespidae). Insecta Mundi 17(3-4): 209-217.

TNC. 2013. TNC maps. The Nature Conservancy. Accessed at http:// maps.tnc.org, 20 April 2015.

Author contributions: RBL collected the data, checked identifications and plotted maps, and RBL and FBN wrote the text.

Received: 8 May 2015

Accepted: 23 September 2015

Academic editor: Georg Fischer 